\title{
A Comparative Study of Frustration Level among Science and Non-Science Students
}

\author{
Dr. Priya Soni Khare \\ Assistant Professor B.Ed. Department Maharana Pratap Govt. P.G. College,Hardoi
}

Our today daily life based on the scientific environment. Science Plays an important role in our day to day life and living. Definitely Science has provided us multiple physical comforts but it has challenged our psychological calmness and composedness. The more the inventions for new medicines and new methods for psychotherapy are being made, the more varieties of frustrations are being evinced.

Frustration is an important psychological, construct which is universally cosmopolitan variable among the mankind this especially plays vital role among the secondary and higher secondary science and non science students, who always struggle with critical and chaotic situations for the survival and to stand on the academic firmament. A magnitude of the factors are responsible for developing frustration among the students a mild degree of frustration, to conquare the situation is essential but the higher degree of the same is venomous for persons and especially for the student's achievements. In this situation person is paralised to a greater extent with reference to his achievement. It is due to fact that he is not in position to channelise his energy in right direction.

\section{Need and Significance:-}

Frustration has been always a social disease which was always responsible for langing behind all the aspect in every walk of life, the social, emotional, economical, mental moral and even physical development of inhabitants can only be plerorished provided national attitude and logical thinkings are released by them. Since an overwhelming majority of the society is affected due to this social evil. Therefore, it was thought relevant to find out level and extent of frustration among different groups of students, the objectives were formulated by taking into account all the dimensions of it and different groups boys, girls, science and non-science.

Such type of study may be helful in the field of education, psychology and sociology. The types of study can solve the problems of adjustment. Fruitful direction can be given to students for progressive thinking.

\section{Statement of the problem:-}

It was planned to study the extent of frustration in science and non science students. So the problem may be stated as- A comparative study of frustration level among science and non science students.

\section{Objectives:-}

1- To find out if there existed any significance of difference between frustration of boys \& girls.

2- To find out if there existed any significance difference between frustration of students belonging to science and non science groups.

3- To find out if there existed any significance of difference between frustrations among students related to different schools.

\section{Hypothesis:-}

Null hypothesis which are given below were formulated which are tested on the basis of statistical ground to come at some definite conclusion.

1- $\quad$ there is not any significance of difference between frustration of boys and girls.

2- $\quad$ There is not any significance of difference between science and non science groups of students.

3- $\quad$ There is not any significance difference between different school.

\section{Definition of Key words}

Frustration:-For achieving any objectives of the life if any sort of hindrance calamities and chaotic situations appear in the way, mental statics deviates to some extent which is called frustration.

Frustrated:-The person who is supporting with frustration is known as frustrated depend upon the extent of frustration to which he is attached.

Student:-An individual who attends a school/college is known as students. For the purpose of this study, students or those learners who are studying in IX class. 
Secondary School:- An educational institution that provides instruction to students up to class $\mathrm{x}$ called as school.

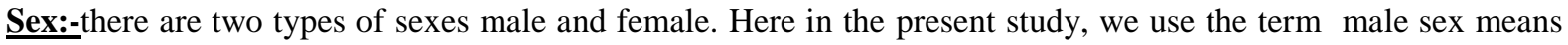
boy and female sex means girls of class ix respectively.

Science students:-those students who have offered science and biology subject are called science students.

Non Science Students:- Those students who have offered art subjects namely hindi, English, Sanskrit, History, Civics and economics are called non science students.

Plan and Procedure:- Descriptive survey method was adopted to conduct the study.

Selection of Tool:- $\quad$ Study related with frustration, hence a scale of frustration is used, which is constructed and standardized by N.S. Chauhan, M.A. M.A. (Cal), L.T., Ph.D. D.Litt., Professor and head Department of Psychology, Meerut University, Meerut and Dr. Govind Tiwari, M.A. Ph.D., R.M.C.(Utkal), Litt., Eminent Scholar (Psychology) Agra University Agra, was applied to measure the level of frustration among the students.

Reliability:-Test-retest reliability of indense was found out on a sample of 50 students and the reliability coefficient was found to be.

Validity:-Validity lies in its capacity to dessify the people to society in the current classes formed on the basis of their socio-economic classes. It was administered on known group of 50 people from the city of Barabanki and $95 \%$ classification were found to be true.

Selection of sample:-For the purpose of this study 300 students of ix Class from government Inter college Barabanki, Govt. Girls Inter college were selected for unfolding the problem. Out of 300 students 150 boys and 150 girls were included in the sample. Samples were selected in such a way so that, science and non science groups may be categorized in the proper way. The breakup of the sample is shown in the following way-

\section{Level of the student:-}

\section{Total Students Taken=300}

Boys (150)

Science Non Słience

(75)

(75)

School wise sample $\mathbf{N}=\mathbf{3 0 0}$
Girls (150)

Science Non Science

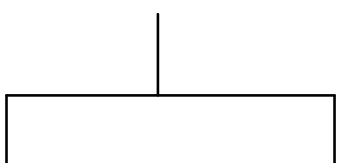

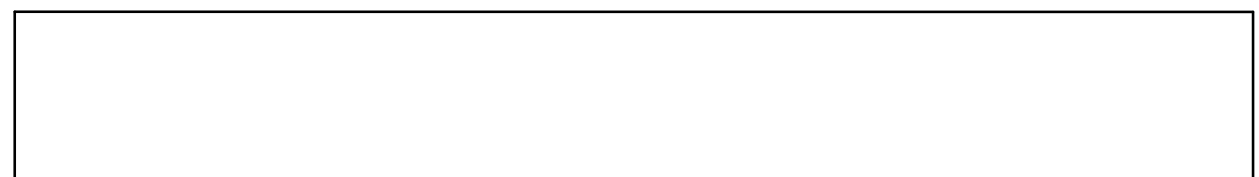

Boys School (150)

Science Non Science

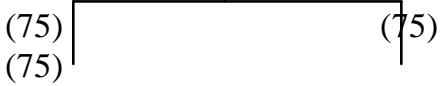

Girls School (150)

Science

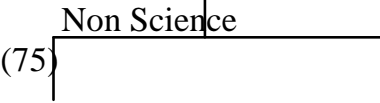

\section{Method of Data Collection}

The principal's permission was sought to administer the test. The willing co-operation of the principal, class teachers and enthusiasm of the students was worthy of appreciation.

The Questionnaire were distributed and collected at the end when students completed the assigned test. Preparation of Data-Sheet and procedure of scoring- 


\section{Techniques of Data Analysis}

The scores obtained on the frustration scale were arranged and tabulated on the master chart. The scores of frustration were arranged on the basis of-

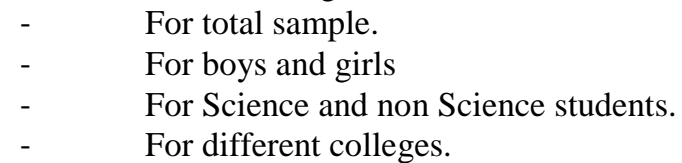

Following statistical analysis were applied to calculate the different aspects-

- $\quad$ To calculate the co-efficient of correction scatter diagram method was applied.

- $\quad$ To find out significance of difference between different groups t-test was applied.

- $\quad$ To calculate mean and standard deviation frequency distribution for respective groups were prepared.

\begin{tabular}{|c|c|c|}
\hline \multirow[b]{2}{*}{ S. No. } & \multicolumn{2}{|c|}{ Analysis and Interpretation of the Data } \\
\hline & Statistics & Values \\
\hline 1 & Mean & 124 \\
\hline 2 & Mdn & 124.50 \\
\hline 3 & Mode & 125.50 \\
\hline 4 & S.D. & 22.89 \\
\hline 5 & Q.D. & 14.74 \\
\hline 6 & $\mathrm{P} 25$ & 109.60 \\
\hline 7 & P50 & 124.46 \\
\hline 8 & P75 & 136.07 \\
\hline 9 & Skewness & 0.065 \\
\hline 10 & Kurtosis & 0.259 \\
\hline
\end{tabular}

Table stand for summary statistics of frustration scores of the total students $(\mathrm{N}=300)$. The values of mean, Median, Mode are 124.00, 124.50, 125.50 respectively, which shows that the values of central tendencies are very close to each other. This is a symptom which gives the placement of this curve to normal probability curve, where all the values of central tendencies are exactly same. The value of P25 is 109.60 which shows that, this (109.60) is the particular score below which 25 percent cases lie. P50 value (124.50) is a particular score which divides the total population in to two clear cut halves which means which 124.50 is a score below and above which 150 or $50 \%$ students are lying P75 values is 139.07 , which means that this is a score below which $3 / 4$ of the total population are existing. The calculated kurtosis value $(\mathrm{KV}=259)$ which reveals that the prepared curve is peaked. This situation may be called as leptokurtic situation. The calculated skewness values is - .065 which denotes that the curve is negatively skewed to the left side. Distribution are said to be skewed negatively or to the left, when scores are massed. At the high limit of the scale (the right end) and are spread out more gradually forwards the low limit of left end. It is also evident from the values of mean and median where the values of median (124.50) is a bit high than the value of mean (124.00).

Significance of difference between frustration boys and girls meand, S.D. and t- value (frustration of boys and girls)

$\begin{array}{lccccccc}\text { S. No. } & \text { Population } & \text { N } & \text { M } & & \text { S.D. } & \text { df } & \text { t-value } \\ 01 & \text { Boys } & & 150 & 127.52 & 24.3 & 298 & 2.60 \\ 02 & \text { Girls } & & 150 & 120.70 & 21.00 & & \end{array}$

Table reveals that the calculated t-value (2.60) is equal the table. The result may be drawn that, there is a significant difference between frustration scores of boys and girls. Thus the formulated null hypothesis is rejected. Table highlights that the mean value (120.70) of girls frustration scores are less than mean value(127.52) of boys frustration scores. Which shows that the boys are more frustrated than the girls? Although girls are supposed to be more frustrated but due to their education and socio economic status, they are having the low level of frustration. Boys are supposed to have a lot of responsibilities and also the society expects more from them, In fact, boys are coming to the institution from comparatively low socio-economic status parental home environment. Therefore they have to face a number of consequences which in turn develops comparatively higher frustration than the girls students who are supposed to have less consequence and responsibilities. Boys have to struggle hard for their existence and even for their survival. It is due to seeking the independency for their real life which is responsible for again developing tension/frustration among their mind. 


\section{SIGNIFICANE OF DIFFERENCE BETWEEN FRUSTRATION OF SCIENCE AND NON SCIENCE} STUDENTS-

Mean S.D. and t- value frustration of science and non science students-

$\begin{array}{lccccccc}\text { S. No. } & \text { Population } & \text { N } & \text { M } & \text { S.D. } & \text { df } & \text { t-value } \\ 01 & \text { Science students } & 150 & 123.45 & 22.75 & & 298 & 0.67\end{array}$

The calculated t-value (0.67) is less than the table t-value (1.97) for df 298 at .05 level therefore, the both groups do not differ significantly. Thus the null hypothesis is accepted. Table also reveals that the mean value (123.45) of frustration scores of science group is less than mean value (125.23) of frustration scores of non-science group. Which shows that the science students are comparatively less frustrate than the non science students. But, due to education and socio-economic status, they are having more or less same level of the frustration. This is aleady assumed that the science student are less frustrated tha the non-science students, because sicence students always have rationale altitudes and ideas, logical thinking and scientific outlook, which are responsible for their frustration. The non science students are always dominated with irrationale attitude and unscientific approaches, therefore, they are more frustrated in relation to their counterpart.

Significance difference between frustration of Government Inter College and Govt. Girls Inter College-

Mean S.D. and t- value frustration score of Govt. Inter College and Govt. Girls Inter College students-

$\begin{array}{clll}\begin{array}{c}\text { S. No. Population } \\ \text { 01 Govt. Inter }\end{array} & \text { N } & \text { M } & \\ \begin{array}{c}\text { College students } \\ \text { 02 Govt. Girls Inter 150 }\end{array} & 150 & 127.57 & 24.31 \\ \text { College students } & 120.70 & 21.00 & \end{array}$

S.D. $\quad$ df $\quad$ t-value

$298 \quad 2.60 \quad \mathrm{p}<.01$

The calculated t-value (2.60) is equal to the table values (2.60) df 298 at .01 level, thus there was found significant difference between Govt. Inter College and Govt. Girls Inter college students is rejected. The mean value (127.57) of G.I.C. student's frustration score and the mean value (120.70) of GGIC students frustration scores also shows that Govt. Girls Inter College students are less frustrated than Govt. Inter College students. In this way the result may be drawn GGIC students are less frustrated than G.I.C. students Due to better teaching facilities, teaching aids, college environment and discipline are responsible for their low level of frustration.

\section{Finding and Conclusion}

- $\quad$ The difference between boys and girls was found to be significant at .01 level therefore null hypothesis will be rejected boys were more frustrated than girls.

- No, any significant difference was not found between frustration of science and non science students. Therefore null hypothesis will be accepted. Due to mean value non-science students were found to be more frustrated than their counterpart.

The difference between Govt. Inter College and Govt. Girls Inter College was found to be significant at .01 level. Therefore null hypothesis will be rejected. Govt. Inter College students were more frustrated than Govt. Girls Inter College.

\section{Conclusion}

Frustration has been proved as a course for society and individuals. It is due to this fact that scientific approach is longing behind, which is essential criteria even for survival of mankind. Frustration is a construct which affect the personality and the way of conduction of an individual to a great extent. Along with educational domain in other domains Physical Social, moral education, political religious and emotional are also affected due to this variable. Therefore, by studying thoughly the level of frustration of the different groups, it can be found out the extent and degree of frustration among the students and according this the educational setup and course should be reformed to give then orientation for having logical approach of scientific attitude in every walk of life. 


\section{Bibliography}

[1]. Ajawani, J.C. and Sharma, R. (2004) Intelligence Variance of Under \& Over Achievers.

[2]. Psycho-Lingua, 4,2, 135-136

[3]. Akhani, P., Rathi, N. and Ipe, A (2003) Moral Educational, Moral Judgement and Personality Characteristics - An Exploratory Study.

[4]. Indian Journal of Psychometry and Education, 34, 1, 47-51 [166]

[5]. Bakshi, Arti (2001) Impact of the Parental Attitudes on the Personality

[6]. Development of Their Children.

[7]. Praachi Journal of Psycho-

[8]. Cultural Dimensions, 17, (2

[9]. Borich, G.D. and Tombari, M.L. (1997)

[10]. Educational Psychology,

[11]. New York: Addison - Wesley Publishers Inc.

[12]. Denscombe, M. (2000) Social Conditions for Stress.

[13]. British Educational Research Journal, 26, 3, 259-265

[14]. Hall, C.S., Lindzey, G. and Campbell, J.B. (1998)

[15]. Theories of Personality,

[16]. New York : John Wiley and Sons

[17]. Hall, C.S., Lindzey, G. and Campbell, J.B. (1998)

[18]. Theories of Personality,

[19]. New York : John Wiley and Sons

[20]. Singh, Harbans (1987) Study Habits of Scheduled Caste Adolescents in

[21]. Relation to Their Intelligence and Achievement Motivation.

[22]. Journal of the Institute of Educational Research,

[23]. 11, (3), 25-29 